and congressane and of the interlocking ring structures known as the catenanes.

The power now placed in the hands of the organic chemist is changing the pattern on which for so long he has worked, but in doing so new and exciting possibilities are opened up. The new organic chemist has been aptly described as "one who is versed in all the disciplines of chemistry from chemical physics to chemical biology and who may be called an organic chemist solely because he happens to work on the chemistry of carbon compounds".

\title{
ROLE OF THE FIELD GEOLOGIST
}

$\mathrm{W}$ E are reminded by Dr. J. V. Harrison in his presidential address to Section C (Geology) that during the time of the French Revolution and also the Napoleonic Wars geology was evolving rapidly as field-work became popular and furnished abundant facts. Search for valuable minerals to keep established trades in existence had been going on for many centuries and had made rocks and ores familiar objects in some societies with special interests. Later, bedded rocks came to be recognized as having 'ages'. In most exposures the lower bed was the older and the higher one the younger. It was not until a century later that it was realized that ages of rocks could be given in terms of years. Fossils were discovored in many formations and their classification undertaken. Their distribution was found to be compatible with an age concept.

Superposition of strata and their fossil sequences were, and still are, the most reliable criteria on which to establish relative age relations. By the beginning of the nineteenth century William Smith had acquired an exceptional knowledge of the rock series in parts of central England and had developed a method for recording his observa. tions by colouring and annotating topographical maps to show the distribution and structure of the rocks. This led him, after years of careful field work, to produce and publish in 1815 a geological map of England. Government-sponsored geological maps of Scotland and Ireland soon followed as well as those of certain countries overseas, for example France. At about the same time, groups of strata in England and Wales were being studied, com. pared, sub-divided and mappod. The description and recognition of the fossils which many of them contained helped to establish the series of 'systems' familiar to all present-day geologists. Rocks of all ages, from the oldest Pre-Cambrian to the youngest Pleistocene, were included in an acceptable working plan, a world-wide classification.

Geologists were thus able to compare observations made in all parts of the world. Whatever the quest, the geologist's instructions were much the same: observe, record and interpret. Each expedition required a map. The course of geological mapping in Britain was determined by the availability of topographical maps published by the Ordnance Survey from 1801 onwards. These provided splendid base maps for the geologist; but in most parts of the world such base maps were not available. Even nowadays much of the time spent in geological explor ation has to be devoted to the production of a base map. Sometimes this is done by using very approximate methods, as in Central America and Borneo, and sometimes by modifying more accurate ones, such as in Persia and Peru, to fit with the requirements of the time-table, but nowadays vertical photographs taken from highflying aeroplanes help to establish accurate base maps. Experience has shown that the value of a geological map depends largely on the clearness of the exposures. Only the maps made in countries where exposures are good are easy to interpret, and where they are not, belp has to be sought from physical and chemical techniquesthis has only been possible since the end of the 'twenties when many useful techniques were refined. Gravity maps, seismic data, electric logs and concentrations of selected elements may help in some aspect of a particular enquiry.

If such geophysical and geochemical help is forthcoming, why, it may be asked, should geologists be retained? The answer lies in the fact that each of these methods yields evidence about only one featuro of the structure beneath. Their value depends largely on the interpretation of the immediate results; the geologist has been trained by seeing and examining many rock structures. Someone must have knowledge of the rocks as they are, that is, as they are exposed on the surface of the Earth. In each generetion they must be studied, and each student must start with something of the heritage handed down; by this means the new geologist can set out with freshly tutored eyes expecting to see something which has previously been overlooked and which may be a key to future revelations. Through discussion and contect with his colleagues in the field, the geologist can tacklo the problems of present geology with enthusiasm yet retain a good sense of proportion. The field geologist is as essential to-dey as he was when field geology first became fashionable 150 years ago.

\section{THE CITY REGION}

$\mathrm{O}$ NE hundred years ago, the British Association, then meoting in Birmingham, concerned itself with the problem of the growth of the industrial town, drawing illustrations from the social conditions which were accompanying the industrialization of the South Staffordshire coalfield. To-day the problems of urban growth are on a regional, rather than a local, scalo and, despite the progress made in town and country planning and in 'environmental control', they present problems of at least equal difficulty and challenge. One of the most difficult of these is the problem of the 'city region', and it is pertinent that Prof. M. J. Wise should choose this as the subject of his presidential address to Section E (Geography).

While much work has boen achieved, or is in progress, the scale of the research effort is not yet adequate. In
Britain greatest attention has been focused on the city region of London. A. G. Powell's paper to Section E in 1960 , and other studies of this and other city regions, have demonstrated the principal features of the changing urban form. These include the growth in scale of the operations of the city and the increasing intensity of their influence over an area of regional scale. The outward movement of population from the inner areas, the result of both plannod and independent removals, has assisted the creation of an outer fringe of rapid population growth. The dispersal of light industry and some types of servicing activity are associated with this movement. By contrast, increasing economic activity in the central areas of the city and in some other parts of the inner area, coupled with improvements in transport opportunities, is linked 